\title{
The Identification of The City on The Legibility and Wayfinding Concepts: A Case of Trabzon
}

\author{
* Dr. Aysel Yavuz 1 (iD), Dr. Nihan Canbakal Ataoğlu 2 iD and Dr. Habibe Acar 3 (iD \\ 1 and 3 Department of Landscape Architecture, Faculty of Forestry, Karadeniz Technical University, Trabzon, Turkey \\ 2 Karadeniz Technical University, Trabzon Vocational High School, Department of Architecture and Urban Planning, Trabzon, Turkey \\ 1Email: ayavuz75@hotmail.com ,2Email: canbakalnihan@hotmail.com ,3Email: habibeacar@hotmail.com
}

\begin{tabular}{l}
\hline A R T I C L E I N F O: \\
\hline Article history: \\
Received 20 June 2019 \\
Accepted 23 July 2019 \\
Available online 1 September \\
2019 \\
\hline \\
Keywords: \\
Legibility; \\
Direction Designs; \\
Circulation; \\
Urban Design; \\
Trabzon.
\end{tabular}

This work is licensed under a Creative Commons Attribution NonCommercial - NoDerivs 4.0. "CC-BY-NC-ND" (c)

This article is published with Open Access at www.ijcua.com

\section{A B S T R A C T}

50) Check for

The concept of wayfinding includes understanding the space and finding direction within the space. But as cities and architectural spaces grow and become more complex, visitors and locals of the space can find it difficult to find direction. For these reasons, for visitors who speak different languages, along with these elements, there is a need for well-designed information and direction-finding graphics and landmarks that have a universal quality. The aim of the study is to explain the concepts of wayfinding and way-finding, defined as "direction-finding" in the literature and to create awareness. Furthermore, to analyze the concept of wayfinding and the direction designs that aim to transform the cities that have become complex into more understandable spaces, through the city of Trabzon and to examine the problems of the city in this context and to make suggestions. In this study, Trabzon will be evaluated with the concepts of legibility and directability and the direction and information designs over the focal point, regions, edges, nodes, roads with which Kevin Lynch has defined the imageable, readable city. A survey was conducted to investigate the spatial information elements and legibility of Trabzon city. Furthermore, to create awareness for other cities with similar problems.

JOURNAL OF CONTEMPORARY URBAN AFFAIRS (2020), 4(2), 1-12. https://doi.org/10.25034/ijcua.2020.v4n2-1

www.ijcua.com

Copyright (c) 2019 Journal of Contemporary Urban Affairs. All rights reserved.

\section{INTRODUCTION}

1.1. Identification of The City, Legibility and Direction Finding

When the growth and resemblance of the cities to each other by becoming ordinary started to be a problem, the first studies on direction finding and legibility of the city were brought forward by Kevin Lynch in the 1960s. In his book City Image, Lynch analyses direction finding in the city by associating it with the legibility of the city and urban images; he states that a city is perceived and encoded to our minds with "roads, monuments, regions, borders and signs".

According to Lynch (1960); "Structuring and defining the environment is a very important skill for all living creatures.

\section{*Corresponding Author:}

Department of Landscape Architecture, Faculty of Forestry, Karadeniz Technical University, Trabzon, Turkey

Email address: ayavuz75@hotmail.com 
To do this, a variety of clues are used: smell, sound, touch, gravity, and even magnetic fields and stimulants, as well as visual sensations such as colour, shape, motion, and light, are utilized. For urbanites who live in modern cities getting completely lost is not a common situation.

The presence of others and special tools such as maps, street numbers, plates, bus numbers help us to find the way. The strategic ring of the directionfinding process is the environmental image, an image where the individual generalizes the outside world in his/her mind. This image is the product of both immediate senses and past experiences used to interpret acquired information and to direct movement."

Bentley defines legibility as the ability to read and understand the environment for options. Readable environments make it easy for people to find their way. If people find out about the environment and what is going on there, they utilize the preferences and advantages of the environment. The meaning of readable environments is that people can obtain clear and accurate images from them. Planners can control only physical planning, permanent images change only by user factor (Bentley, 1985; Yavuz, 2009).

According to Kaplan and Kaplan (1989); legibility is an environmental feature that allows the person to explore his surroundings without getting lost (Yavuz, 2009). According to Evans; legibility is to enable people to understand the plan of a place and the activities it involves (Carmona et al., 2003; Yavuz, 2009).

Sternberg explains legibility in terms of being easily understandable, comprehensible and safe for either residents or foreigners by creating effective differences in the meaningful parts of the whole and between these parts in urban planning (Sternberg, 2000; Yavuz, 2009).

Direction-finding is that individuals can find their way to their targets without delaying or experiencing undue worry. On the basis of the concept, there is the concept of "spatial orientation" which means that the individual places himself/herself into the mental representations of the environment [(Sönmez \& Önder, 2015), cited from Peponis et al. (1990)]. One of the most effective concepts in showing up and progressing direction finding and related studies is the concept of legibility. Direction-finding is considered as a feature of readable environments; the environments that provide the necessary environmental information for the direction-finding behaviour and which enable this knowledge to be grasped and understood are expressed as the readable environment. This is possible with the fictionalization of the environment with defined and distinct elements; by means of comprehending the defined elements, it becomes easier to move to the target and direction finding in that environment [(Sönmez \& Önder, 2015), cited from Passini $(1984,1996)]$. We perceive the place and our location with the questions of "Where am I, where am I going, and how should I reach it". Legibility and directionfinding are two concepts associated with each other.

Lynch, in his book "Urban Image", describes a legible city as textures that are created with definable elements and which can be comprehended visually. At the same time, by establishing relations with the urban images; he defined a readable city as a whole texture of which the regions, borders and roads can be easily identified.

Lynch, in the continuity of the definitions of legibility, mentions the importance of the individual's ability to find his/her direction properly and to move easily. According to Kevin Lynch, five main elements for the mental image of a city and, accordingly, for the legibility and direction finding in the city can be defined as follows:

Roads: These can be streets, pedestrian roads, public transport areas, canals and railways. These elements are dominant in the image of many people. People observe the city on the move and perceive other environmental elements on these roads and relate to the whole.

Edges: They function as a boundary between two regions. Coasts, railways, development zone borders and walls are examples of edge elements. The edges may be walls that allow passing at some of its points and that connect two regions, and the connecting points connecting two regions. The edge elements that hold the generalized areas together, such as in the cities of which the main lines are determined with water or walls; are important elements that many people use to find directions.

Regions: Regions are perceived as twodimensional areas; they form medium or largescale parts of the city. The observer feels as entering into these areas psychologically. These can be recognized by some of their common determinant characters.

Nodal / Focal Points: Nodal points are strategic points; they are intense focal points when travelling from one point to another. In particular, intersections, squares as meeting points can form nodal points.

Signal elements: They create the point reference source. They are often easily defined physical formations that are not entered; like a building, a sign plate, a shop, or a mountain. They may be within the city or at a certain distance. In this way, they symbolize a fixed direction for any practical use; like the city's towers, golden domes or high hills. 
The elements Lynch defines create spatial information for direction finding and legibility. Legibility is designed with spatial guidance tools that are integrated into the perception and definition process of cities.

Spatial direction tools; with the elements Kevin Lynch has defined, can be listed as follows:

- Legibility of circulating arteries

- Focal points

- Definable areas, squares

- Accessories, materials, colors, textures, lighting

- Creating spaces with identity.

These items can be used as an effective design tool in direction. But like cities, architectural spaces grow and become more complex, visitors and locals can find it difficult to find direction. For these reasons, along with these elements, there is a need for well-designed information and direction graphics and landmarks of a universal nature for those who speak different languages.

\subsection{Information and Direction Design}

As cities, architectural spaces grow and become more complex, visitors and locals started to have difficulty in finding directions; a need for information boards, direction signs and landmarks has arisen. There is a need for well-designed information and direction graphics and landmarks of a universal nature for those who speak different languages. Information design and direction design, as a sub-branch of graphic design, is a field of expertise that is based on interdisciplinary cooperation covering many disciplines such as architectural design, interior design, urban design, landscape design, industrial design, communication, ergonomics, psychology and computer technologies. Information and direction designs, a sub-branch of graphic design that makes information readable and accessible for all, have been important components of urban design and spatial design by creating spatial image and corporate identity (Figure 1).

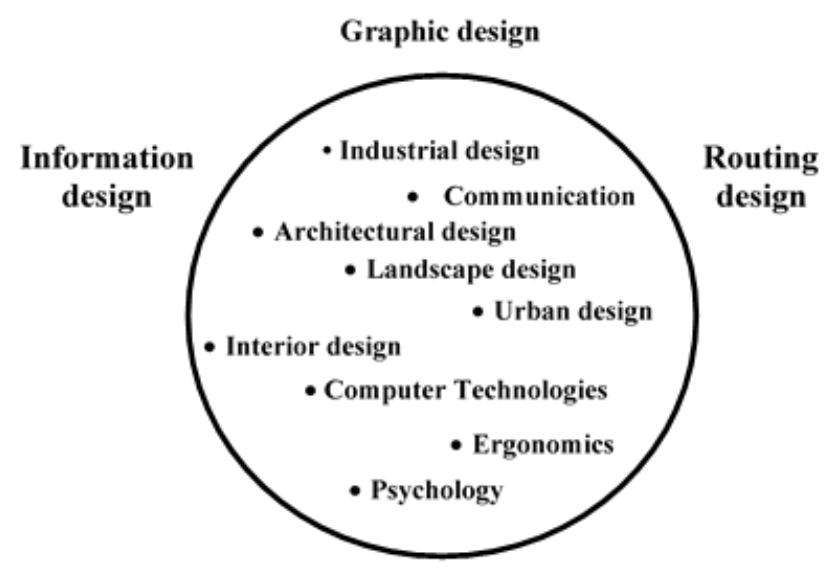

Figure 1. Interdisciplinary cooperation in information and direction design.

\subsubsection{Information Design}

Information design is a design field that organizes and presents the information needed by its user in a fast and understandable way. Making life easier, making the time used efficiently and preventing confusion are among its primary tasks. In this field, which we can explain as the design of information, the primary objective is to convey the information in the simplest, clearest and most understandable way to others. It is necessary for the user who is in constant information bombardment to perceive the environment more clearly (ilisulu, 2017). Information design, which is one of the most basic areas of graphic design, works on how to transfer information better to the user. Graphic language, especially in metropolitans, is preferred in terms of being universal. It is the language that can be accessed and understood by everyone from the illiterate masses to the tourists who do not know the local language of the city; the language that the visual communication and graphic design would recommend. Especially considering the urban life with a fast tempo, the fast transfer of this information also becomes important. Simple but very well-designed directions, signs that can be understood by everyone, directional systems that can be associated with each other and that can be followed, consistent composition, colour and typography are the elements that should be designed (TaşÇloĞLu \& Aydin, 2015).

Highways, city entrance signs, airports, terminals, campuses, Olympic facilities, shopping centres, cultural centres, hospitals, exhibition and fairgrounds are the places where information and direction designs are used to find direction. In big and crowded cities, symbols and pictograms used in the international arena, information and direction graphics are the tools that regulate social relations and provide communication. The pictogram or pictograph is a symbol representing a furnishing, an object, a place, a function, a concept by way of illustration (Figure 2).

In the context of environmental graphic design, pictograms are used in direction and marking sequences, especially in large and complex spaces. Pictograms are used to direct and inform people in many public spaces such as airports, train stations, bus stations, shopping centres, business centres, museums, hotels, hospitals etc. Therefore, it is very important that the pictograms can be easily understood by different human masses (Dur, 2011 ). 


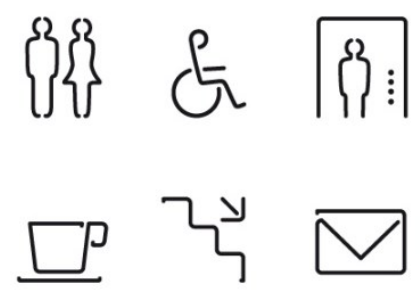

Figure 2. Symbolic expression with pictogram (URL-1, 2017).

\subsubsection{Direction Design}

Direction design is an information design field that aims to enable users to find their destination in open or closed areas. The direction design consists of visual designs intended to guide the user in a certain direction. The marking design is a visual sign indicating the point of arrival to the user. These marks are the markers that specify a name and a function of that place. For example, street markings guide pedestrians, while guiding them, also make it easy for them to read the environment. Being able to see an important building far away helps pedestrians know where they are and whether they go in the right direction. A marked street will be much easier to perceive, read and familiar (Kolody, 2002; Yavuz, 2009). Marks such as door writings, floor numbers, building names etc. are within the scope of the marking design. "The direction and marking design guides the pedestrian or vehicle traffic in main entrances, road junctions, arrival and exit points, by combining graphic elements such as typography, symbols and arrows ((Gibson, 2009): 50, cited by: (TaşÇloĞLu \& Aydin, 2015)).

The principles of a successful direction design can be listed as follows(Ataoğlu, 2009):

- It should support user and visitor experience, make finding directions easier.

- It should be guiding and explanatory for those visiting for the first time.

- It should help at decision points.

- It should create a sense of space.

- It should create an open and consistent information system.

- The route for reaching the point of destination and leaving the space and its guidance should also be designed.

- The message should be open and clear, should be understood easily.

- It should give direction to the target and be supportive at each stage.

- There should not be information and marking confusion.

- It should support creating corporate identity, brand value and image.

It should add aesthetic value to space with its colour, form, typeface and graphic designs.
For information-direction design

Pictogram, typography, infographic, maps, schema and graphs, I am here maps, direction arrows, landmarks, entry signs are used.

\section{FIELD SURVEY}

In this study, the city of Trabzon will be evaluated with the concepts of legibility and directability and the direction and information designs over the focal point, regions, edges, nodes, roads with which Kevin Lynch has defined the imageable, readable city. In particular, it aims to determine the perceptions and direction attitudes of university students for Trabzon city and the city square. A survey was conducted to investigate the spatial information elements and legibility of the city of Trabzon.

In this framework, the aim of the study to analyse the concept of legibility and direction designs that intend to transform the cities into more understandable spaces through the city of Trabzon, the square and its surroundings and to examine the problems of the city in this framework and to make suggestions. Furthermore, to create awareness for other cities with similar problems.

\subsection{Study Area}

Trabzon is a port city founded in the 7th century B.C. as one of the Ionian colonies of the Miletus city-state on the Aegean coast of Anatolia (Kayaoglu et al., 1997). Trabzon has a colourful identity and geographical location with the fact that it has the largest port of the Eastern Black Sea, its geographical and topographical position, hosting many different cultures such as Persians, Romans, Byzantines, Genoese and Ottomans, and the reflection of this dynamic diversity in the space (Figure 3-4).

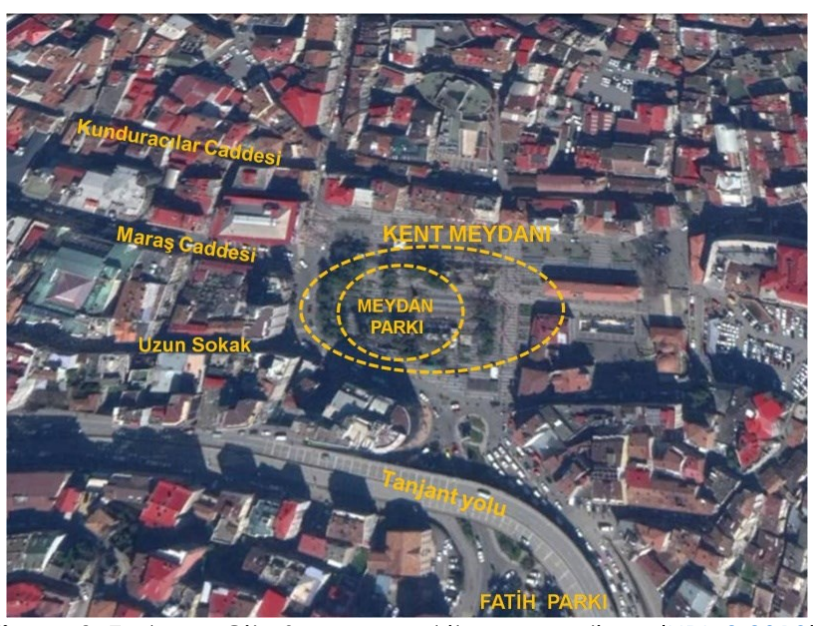

Figure 3. Trabzon City Square and its surroundings (URL-2 2019). 


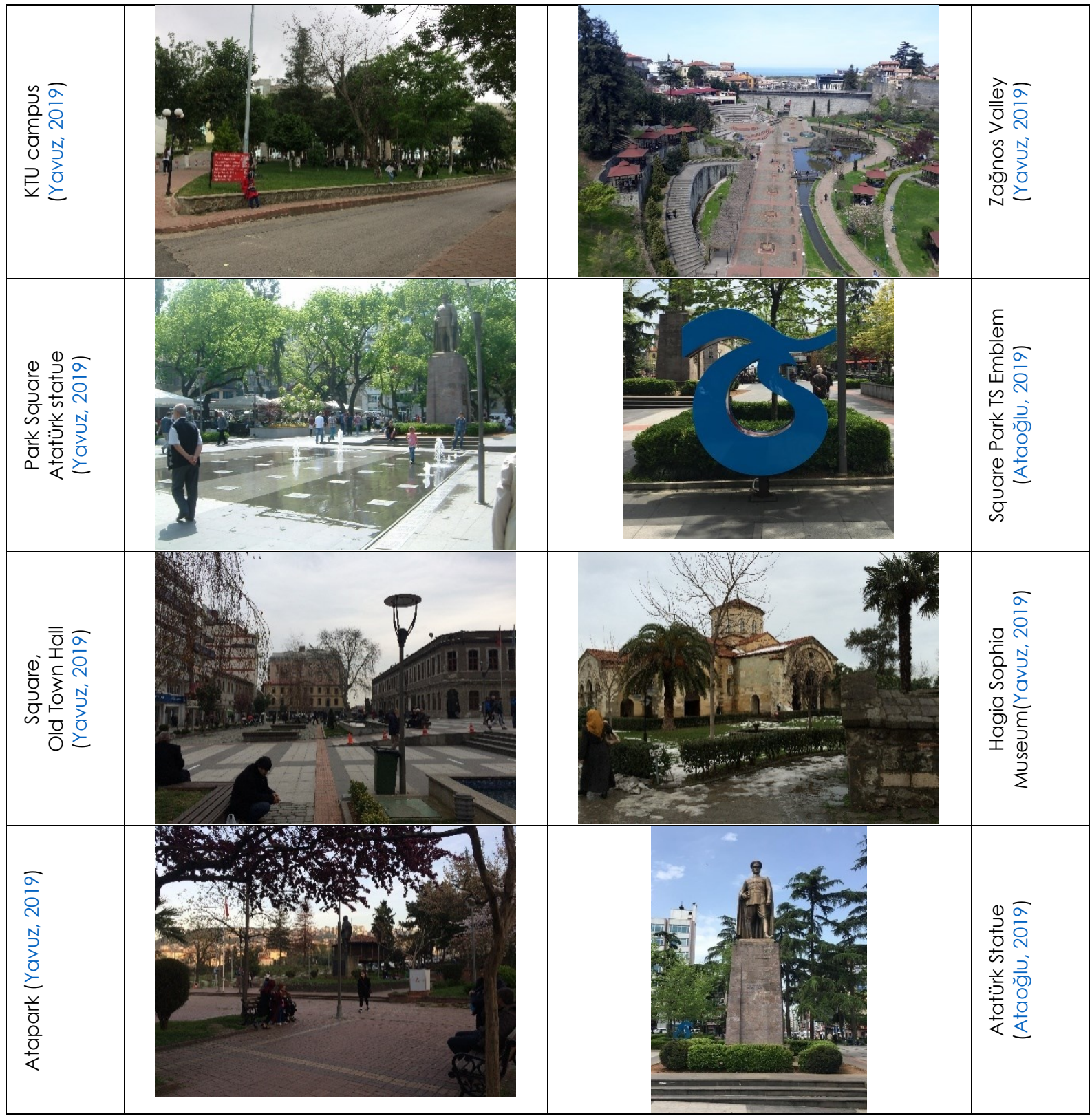

Figure 4. Images of the study field (Ataoğlu, 2019; Yavuz, 2019).

\subsection{Participants}

Universities are in interaction with the city where they were founded in addition to their basic functions such as education and training. This expectation supports the revival of the city and it goes beyond its immediate environment, contributes to and supports the development of its region (Demirbaş et al., 2017). At the city center of Trabzon, which is a university city, students coming from different provinces of Turkey for education purposes live with the residents. A total of 116 university students from the departments of Landscape Architecture, Architecture and Interior Architecture participated in this study to determine the university students' perception of Trabzon city and city square and their direction attitudes. The questionnaire form contained questions about the determination of demographic data and the determination of the places forming an image in the minds of the users in the square and its immediate surroundings. In the questionnaire, there were 10 questions in total. The questionnaire was conducted with students randomly selected from different classes from each of the three departments. The questionnaire was completed in approximately 5 minutes with each participant. The study was conducted in April 2019. $75 \%$ of the participants were female and $40 \%$ were between 16 and 20 years old. $28 \%$ of the total sample was represented as Trabzon residents. Although the majority of the students were not from Trabzon, it was found that they mastered important components about Trabzon during their stay (Table 1). 
Table 1. Percentage (\%) distribution of demographic characteristics of participants.

\begin{tabular}{llc}
\hline & & Percentage(\%) \\
\hline Gender & Male & 75 \\
& Female & 25 \\
\hline Age & $16-20$ & 40 \\
& $21-25$ & 52 \\
& $26-30$ & 8 \\
\hline & Landscape & \\
& Architecture & 48 \\
Department & Architecture & 35 \\
& Interior & \\
& Architecture & 17 \\
\hline \multirow{4}{*}{ Class } & 1st grade & 26 \\
& 2nd grade & 34 \\
& 3rd grade & 24 \\
\hline Neighborhood & Kth grade & 16 \\
& Kalkınma & 40 \\
& Konaklar & 25 \\
& Otherscl & 8 \\
Where are you & Trabzon & 27 \\
\cline { 2 - 2 } from? & Others & 28 \\
\hline How long have & 1 year & 72 \\
you been living & 2 year & 21 \\
in Trabzon? & 3 year & 23 \\
& 4 year & 17 \\
& More than 5 years & 13 \\
\hline Where are you & Home & 26 \\
staying? & Dormitory & 52 \\
\hline & & 48 \\
\hline
\end{tabular}

Within the scope of the study, the surveyed individuals were asked to make evaluations about direction finding and direction for the city they live in and the city centre and its immediate surroundings. $29 \%$ of the participants stated that they could not easily find the structures or institutions in the city square and its immediate surrounding, $20 \%$ stated that they had problems in finding direction, $69 \%$ stated that they have lost the way for their destination and experienced delays. In addition, they stated that there were serious deficiencies in the number and quality of directional signs (Table 2).

Table 2. Percentage (\%) distribution of the participants' data related to direction finding and direction.

\begin{tabular}{|l|l|l|}
\hline Questions & Yes \% & No \% \\
\hline $\begin{array}{l}\text { S3.Can you easily find existing } \\
\text { structures/institutions? }\end{array}$ & 71 & 29 \\
\hline S4.Can you find your way easily? & 80 & 20 \\
\hline S5.Have you ever lost your way? & 31 & 69 \\
\hline $\begin{array}{l}\text { S7.Is it enough for the number of direction } \\
\text { signs? }\end{array}$ & 20 & 80 \\
\hline $\begin{array}{l}\text { S8.Is the quality of the signboard that } \\
\text { where you are and where you want to go } \\
\text { sufficient? }\end{array}$ & 22 & 78 \\
\hline
\end{tabular}

It was intended to evaluate whether Trabzon city centre and its immediate surroundings were readable places; what their perceivable elements were; what the reference points related to the city centre were; and the presence of elements, structures or places defining the city of Trabzon. In this context, the answers of the participants showed us that the people formed images that were highly visually perceivable in the study area. $54,3 \%$ answered the question "The place you indicate as address in the city square and its immediate surrounding when you want to meet a friend" as the Square Park. $8,8 \%$ of the participants stated that they preferred the cafes in the immediate area, $6,9 \%$ preferred Forum AVM as the meeting place. According to the answers, the most preferred values were "Nodal point" with $55,2 \%$ and "landmark" with $31 \%$ amongst the five elements defining the city. These results show that the nodal points and landmark locations as the meeting point are more preferred, easily remembered and easily accessible places (Table 3).

Table 3. Percentage (\%) distribution of the participants' meeting point preferences.

\section{S1. Town square and nearby}

When you want to meet a friend, where do you meet?

\begin{tabular}{|c|c|c|c|c|c|c|}
\hline $\mathrm{N}$ & $\begin{array}{l}\text { Number of people } \\
\text { percentage\% }\end{array}$ & Paths & District & Edges & Nodes & Landmark \\
\hline Meydan Park & 54,3 & & & & $\checkmark$ & \\
\hline Cafes & 8,8 & & & & & $\checkmark$ \\
\hline Forum Mall & 6,9 & & & & & $\checkmark$ \\
\hline Atatürk Statue & 6,9 & & & & & $\checkmark$ \\
\hline Uzun Street & 6,0 & $\checkmark$ & & & & \\
\hline Trabzonspor Emblem & 4,3 & & & & & $\checkmark$ \\
\hline KTU (University) & 3,4 & & $\checkmark$ & & & \\
\hline Konaklar District & 2,6 & & $\checkmark$ & & & \\
\hline Point Stationery & 1,7 & & & & & $\checkmark$ \\
\hline Dormitory & 1,7 & & & & & $\checkmark$ \\
\hline Arzum Market & 9 & & $\checkmark$ & & & \\
\hline Beşirli District & 9 & & $\checkmark$ & & & \\
\hline Lc Waikiki (Clothing Store &, 9 & & & & & $\checkmark$ \\
\hline Tanjant Taxi Stops &, 9 & & & & $\checkmark$ & \\
\hline Total & 100,00 & 6,0 & 7,8 & 0 & 55,2 & 31,2 \\
\hline
\end{tabular}


$36,2 \%$ of the participants answered the question "The first place/object that comes to your mind in the city square and its immediate surroundings" as Atatürk statue, 15,5\% as Trabzonspor emblem, 9,5\% as Uzun Street and $6 \%$ as cafes and restaurants. According to the answers, the most preferred were "landmark" values with $77,7 \%$, and "Regions" with
$17,4 \%$ amongst five elements defining the city. These results show that the places and regions that have a landmark feature are preferred more in the city square and that they are places that can easily form an image in memory and be remembered (Table 4).

Table 4. Percentage (\%) distribution of place/object preferences of the participants that first comes to mind on the city square and its close vicinity

\section{S2. Town square and nearby}

What is the first place/object to think

\begin{tabular}{|c|c|c|c|c|c|c|}
\hline \multicolumn{7}{|l|}{$\begin{array}{l}\text { Items } \\
\text { percentage\% }\end{array}$} \\
\hline Atatürk Statue & 36,2 & & & & & $\checkmark$ \\
\hline Trabzonspor Emblem & 15,5 & & & & & $\checkmark$ \\
\hline Uzun Street & 9,5 & $\checkmark$ & & & & \\
\hline Cafes-Restaurants & 6,0 & & & & & $\checkmark$ \\
\hline Forum Mall & 5,2 & & & & & $\checkmark$ \\
\hline Faculty of Architecture & 3,4 & & & & & $\checkmark$ \\
\hline Tanjant taxi stops & 2,6 & & & & $\checkmark$ & \\
\hline KTU (University) & 2,6 & & $\checkmark$ & & & \\
\hline Atatürk Pavillion & 2,6 & & & & & $\checkmark$ \\
\hline Atapark & 1,8 & & $\checkmark$ & & & $\checkmark$ \\
\hline My home & 1,7 & & & & & $\checkmark$ \\
\hline Sümela Monastery & 1,7 & & & & & $\checkmark$ \\
\hline Square- Sitting Furnitures & 1,7 & & & & & $\checkmark$ \\
\hline Boztepe & 1,7 & & $\checkmark$ & & & \\
\hline Point Stationery & 9 & & & & & $\checkmark$ \\
\hline Arzum Market & 9 & & & & & $\checkmark$ \\
\hline Old Town Hall & 9 & & & & & $\checkmark$ \\
\hline Coast & 9 & & & $\checkmark$ & & \\
\hline Airport & 9 & & $\checkmark$ & & & \\
\hline Keloğlan Statue & 9 & & & & & $\checkmark$ \\
\hline Cephanelik Restaurant & 9 & & & & & $\checkmark$ \\
\hline Zağnos Valley & 9 & & $\checkmark$ & & & \\
\hline Kanuni Home & 9 & & & & & $\checkmark$ \\
\hline Total & 100,00 & 9,5 & 17.4 & 0,9 & 2,6 & 77,7 \\
\hline
\end{tabular}

$37,1 \%$ of the participants answered the question "Where would your reference point be when you describe an address in the city square and its immediate surrounding to someone?" as the square park, $14,7 \%$ as Uzun Street, $8,6 \%$ as Atatürk statue and $6,9 \%$ as KTÜ (Karadeniz Technical University). According to the answers, the most preferred values were "Nodal point" with $39,7 \%$ and "landmark" with $29,3 \%$ amongst the five elements defining the city. These results show that the nodal points and places with a landmark feature are mostly preferred related to reference point preferences, that they are important for direction in urban spaces as they are places that form an image in the memory and can be easily remembered (Table 5). 
Table 5. Percentage (\%) distribution for participants' preference of reference point when describing an address in the city square and its immediate surroundings.

S6. Town square and nearby

Where is your reference point when describing an address?

\begin{tabular}{|c|c|c|c|c|c|c|}
\hline \multicolumn{7}{|l|}{$\begin{array}{l}\text { Items } \\
\text { percentage\% }\end{array}$} \\
\hline Square & 37,1 & & & & $\checkmark$ & \\
\hline Uzun Street & 14,7 & $\checkmark$ & & & & \\
\hline Atatürk Statue & 8,6 & & & & & $\checkmark$ \\
\hline KTU (University) & 6,9 & & $\checkmark$ & & & \\
\hline Cafes-Restaurants & 6,1 & & & & & $\checkmark$ \\
\hline Sea & 5,2 & & & $\checkmark$ & & \\
\hline Arzum Market & 3,4 & & & & & $\checkmark$ \\
\hline Old Town Hall & 2,6 & & & & & $\checkmark$ \\
\hline Taxi Stops & 2,6 & & & & $\checkmark$ & \\
\hline Meydan Mosque & 1,7 & & & & & $\checkmark$ \\
\hline Kalkınma District & 1,7 & & $\checkmark$ & & & \\
\hline Trabzonspor Emblem & 1,7 & & & & & $\checkmark$ \\
\hline Coast & 1,7 & & & $\checkmark$ & & \\
\hline Atm & 1,7 & & & & & $\checkmark$ \\
\hline Ziraat Bank & 1,7 & & & & & $\checkmark$ \\
\hline Koton (Clothing store) &, 9 & & & & & $\checkmark$ \\
\hline Forum Mall &, 9 & & & & & $\checkmark$ \\
\hline Maraş Street &, 9 & $\checkmark$ & & & & \\
\hline Total & 100,00 & 15,6 & 8,6 & 6,9 & 39,7 & 29,3 \\
\hline
\end{tabular}

$25 \%$ of the participants answered the question "What is the place/structure you mostly use in the city square and its immediate surroundings?" as Square park, $21,6 \%$ as Uzun Street, $13,8 \%$ as KTÜ (Karadeniz Technical University), 9,5\% as cafes and restaurants. According to the answers, the most preferred were "landmark" values with $40,8 \%$ and
"Regions" with $34,6 \%$ amongst the five elements defining the city. These results showed that places with a landmark value and regions were mostly preferred with regards to the most used place/structure in the city square (Table 6).

Table 6. Percentage (\%) distribution of the most used place/structure preference of the participants in the city square and its immediate surroundings.

\section{S9. The town square and nearby}

Your favourite place/structure

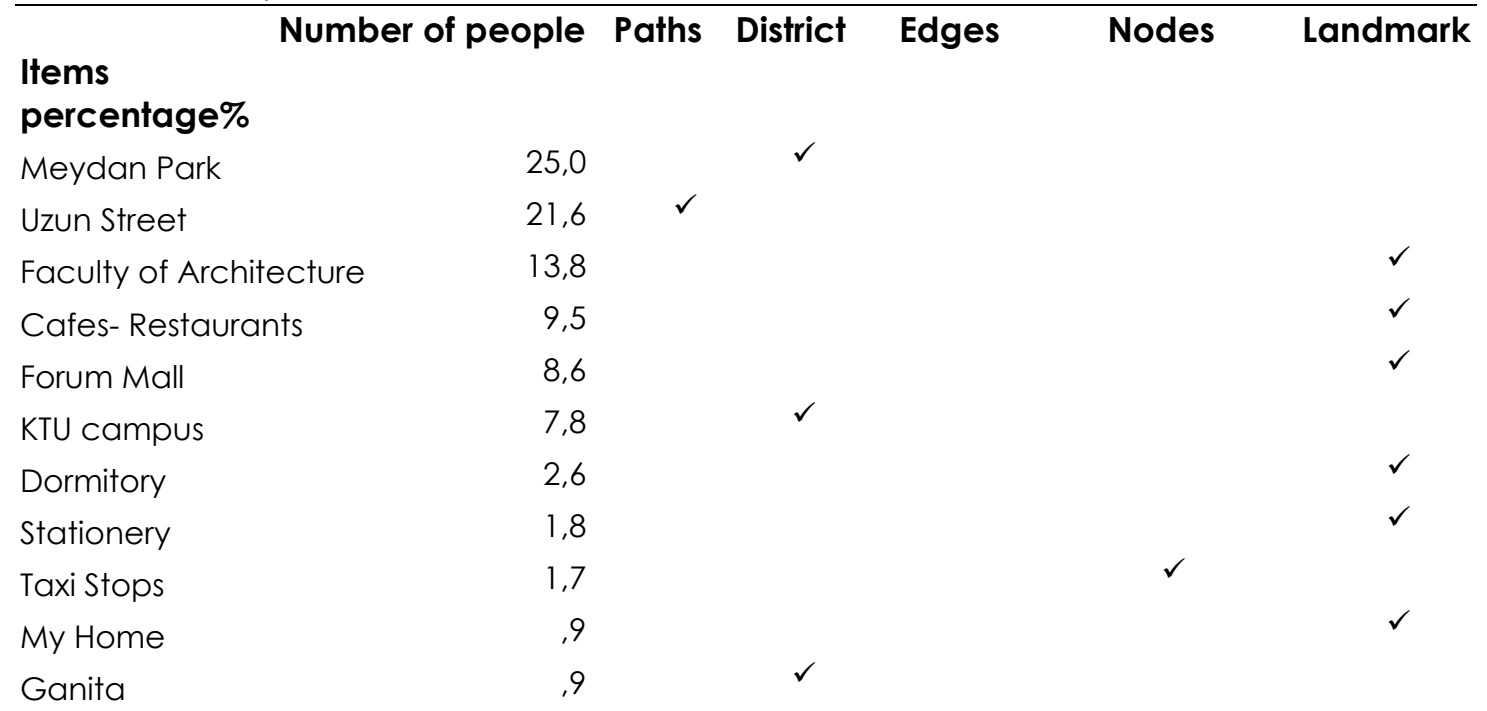




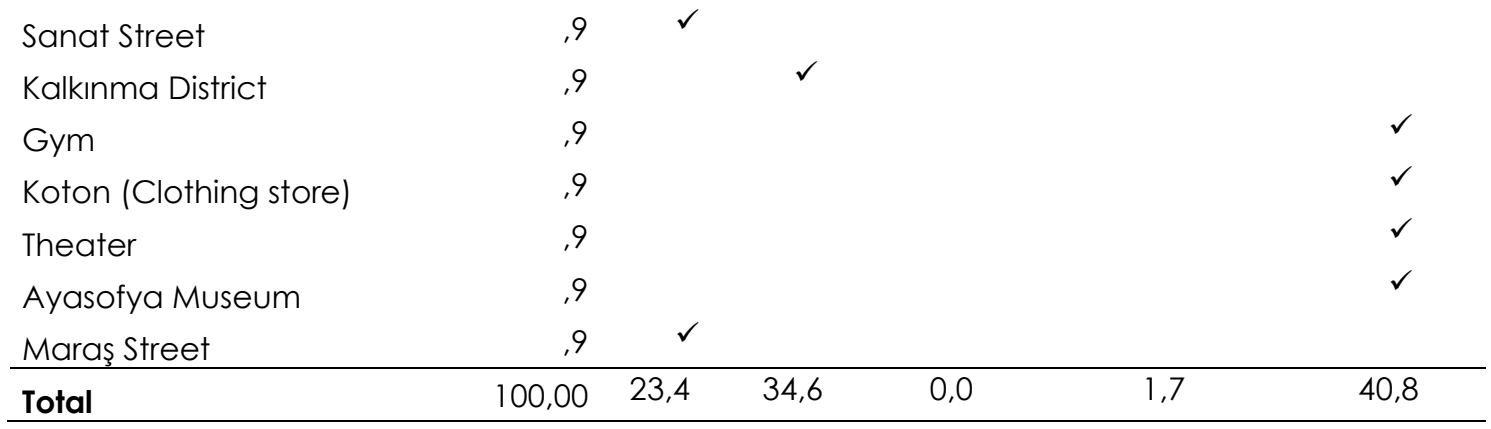

Participants were asked to rank the place/structure/elements that define Trabzon in order of importance. In the rank of the $1^{\text {st }}$ choices, the Square Park with 24, 1\%, Uzungöl with 10,3\% and Sümela Monastery were prominent. Amongst the second choices of the participants that define Trabzon, Uzungöl with 12,9\%, the Square Park with $11,2 \%$, Sümela Monastery with $10,3 \%$ were emphasized. In the $3^{\text {rd }}$ choice of the participants, the Square Park with 18,1\%, KTÜ (Karadeniz
Technical University) with $10,3 \%$ and Sümela Monastery with 9,5\% were prominent. These results showed that the Square Park was an important nodal point and that Sümela Monastery, Uzungöl, KTÜ, Boztepe and Uzun Street were the most important places/structures/elements that define the city.

Table 7. The percentage (\%) distribution of place/structure/item preferences that define Trabzon in order of importance of the participants.

\section{S10.Describe the Trabzon places/structure/elements ( 3 words in order of importance)}

\begin{tabular}{|c|c|c|c|c|c|}
\hline \multirow[t]{2}{*}{ 1st choice } & & \multicolumn{2}{|l|}{ 2nd choice } & \multicolumn{2}{|l|}{ 3rd choice } \\
\hline & $\begin{array}{l}\text { ople } \\
\text { age\% }\end{array}$ & \multicolumn{2}{|c|}{$\begin{array}{r}\text { Number of people } \\
\text { percentage } \%\end{array}$} & \multicolumn{2}{|c|}{$\begin{array}{r}\text { Number of people } \\
\text { percentage } \%\end{array}$} \\
\hline Meydan Park & 24,1 & Uzungöl & 12,9 & Meydan Park & 18,1 \\
\hline Uzungöl & 10,3 & Meydan Park & 11,2 & KTU (University) & 10,3 \\
\hline Sümela Monastery & 10,3 & Sümela Monastery & 10,3 & Sümela Monastery & 9,5 \\
\hline Uzun Street & 8,6 & Boztepe & 10,3 & Boztepe & 9,5 \\
\hline KTU (University) & 7,8 & KTU (University) & 9,5 & Ayasofya Museum & 7,8 \\
\hline Ayasofya Museum & 6,0 & Forum Mall & 8,6 & Uzungöl & 6,9 \\
\hline Atatürk Pavillion & 6,0 & Atatürk Pavillion & 6,0 & Forum Mall & 5,2 \\
\hline Trabzonspor & 6,0 & Uzun Street & 5,2 & Uzun Street & 3,4 \\
\hline Boztepe & 4,3 & Ganita & 3,4 & Trabzonspor & 3,4 \\
\hline Ganita & 3,4 & Ayasofya Museum & 2,6 & Beşirli Coatal district & 2,6 \\
\hline Beşirli Coatal district & 1,7 & Beşirli Coatal District & 2,6 & Valleys & 2,6 \\
\hline ForumMall & 1,7 & Stadium & 1,7 & Ganita & 1,7 \\
\hline Stadium & 9 & Kalkınma District & 1,7 & Atatürk Pavillion & 1,7 \\
\hline Kalkınma District & 9 & Valleys & 1,7 & Kalkınma District & 1,7 \\
\hline Ortahisar District & 9 & Sürmene, Çamburnu & 1,7 & Moloz & 1,7 \\
\hline Valley & 9 & Moloz & 9 & Bread & 1,7 \\
\hline Akçaabat & 9 & Trabzonspor & 9 & Nature & 1,7 \\
\hline Sea & 9 & $\mathrm{Laz}$ & 9 & Urban Museum & 1,7 \\
\hline Eyof Park & 9 & Pide(A type of Bread) & 9 & Konaklar District & 9 \\
\hline Sürmene, Çamburnu & 9 & Stadium & 9 & Çömlekçi District &, 9 \\
\hline Of & 9 & Fiddle & 9 & Ortamahalle District &, 9 \\
\hline Cephanelik Restaurant & 9 & Nature & 9 & Maraş Street &, 9 \\
\hline \multirow[t]{6}{*}{ Hamamizade } &, 9 & Sea & 9 & Plateaus &, 9 \\
\hline & & Cemil Usta Restaurant & 9 & Botanik Park &, 9 \\
\hline & & Atatürk Statue & 9 & High Buildings &, 9 \\
\hline & & Kostaki Residence & 9 & Altındere &, 9 \\
\hline & & Kunduracilar Street & 9 & Sea &, 9 \\
\hline & & & & Cemil Usta Restaurant &, 9 \\
\hline
\end{tabular}

Whether there was a difference in answers given to the questions in the questionnaire according to departments was evaluated with Crosstab. Amongst the questionnaire questions, it was observed that the differences of the departments of the students were effective only on the questions of S1, S2, S7, S8 and S9. Amongst the answers, the quantity (and strength) of the effect of the departmental differences were analysed with the 'Cramer's V' test. The Cramer $V$ values range from 0 to 1 , the values between $0-30$ (or 040 ) indicate the presence of a weak relationship, values between 31-60 (or 41-70) indicate a moderate relationship, and values between 61- 
100 (or 71-100) indicate a strong relationship (Özbay, 2008). S1 Cramer V value was 50, S2 Cramer V value was 57, S3 Cramer V value was 50 and the effect of Landscape Architecture, Architecture and Interior Architecture departments on the answers to these questions were moderate. S7 Cramer $V$ value was 23 , S8 Cramer $\vee$ value was 25 , and these showed that the effect on the answers to these questions was low according to the departments (Table 8).

Table 8. The effect of departmental differences on the questions Chi-Square and Cramer $V$ values.

\begin{tabular}{clllll} 
& Value & df & $\begin{array}{l}\text { Asymptotic } \\
\text { Significance } \\
\text { (2-sided) }\end{array}$ & $\begin{array}{l}\text { Kramer } \\
\text { V }\end{array}$ \\
\hline S1 & $\begin{array}{l}\text { Pearson } \\
\text { Chi- } \\
\text { Square }\end{array}$ & 59,704 & 38 &, 014 &, 507 \\
S2 & $\begin{array}{l}\text { Pearson } \\
\text { Chi- } \\
\text { Square } \\
\text { S7 }\end{array}$ & 74,193 & 46 &, 005 &, 566 \\
& $\begin{array}{l}\text { Pearson } \\
\text { Chi- } \\
\text { Square } \\
\text { S8 }\end{array}$ & 6,246 & 2 &, 044 &, 232 \\
& $\begin{array}{l}\text { Pearson } \\
\text { Chi- } \\
\text { Square } \\
\text { Pearson }\end{array}$ & $7,676 a$ & 2 & 0,022 &, 499 \\
Chi- & $57,856 a$ & 36 &, 012 & \\
Square & & & & \\
\hline
\end{tabular}

\section{RESULTS AND SUGGESTIONS}

Legibility is an important issue in our developing cities with rapid urbanization and population growth. In this study, which addressed this problem, a total of 116 university students from the departments of Landscape Architecture, Architecture and Interior Architecture participated to determine the university students' perception of Trabzon city and city square and their direction attitudes.

Within the scope of the study, the surveyed individuals were asked to make evaluations about direction finding and direction for the city they live in and the city centre and its immediate surroundings.

It was evaluated whether Trabzon city centre and its immediate surroundings were readable places; what their perceivable elements were; what the reference points related to the city centre were; and the presence of elements, structures or places defining the city of Trabzon.

In this context, the answers of the participants showed us that the people formed images that were highly visually perceivable in the study area.

These results show that the nodal points and places with a landmark feature are mostly preferred related to reference point preferences, that they are important for direction in urban spaces as they are places that form an image in the memory and can be easily remembered.
The majority of the participants, as Lynch stated, it was shown that a city would be perceived and encoded to our minds with "roads, monuments, regions, borders and signs". When the elements of Kevin Lynch were analysed for the city of Trabzon in the light of the surveys, it can be explained as follows:

- Roads: Uzun Street, where the urban transportation is provided and which was pedestrianised, Maraş Street and the Tanjant Road where the vehicle passage is provided were prominent as the dominant elements.

- Edges: For Trabzon, which is a sea city, the coast, seaside and historic city walls constitute important points of reference as border elements.

- Regions: The city square and the coastal region in its surrounding and Karadeniz Technical University campus, which is the residential area of Trabzon, which is a university city, the shopping centre region near its surroundings attract attention as the regions. Uzungöl, which is far from the city, makes its presence felt with its different character.

- Nodal / Focal Points: The squares, which are urban open spaces surrounded by buildings, where various activities take place, are important triangulation points that give character and identity to cities. In the city centre of Trabzon, Atatürk Square Park has created a city image as a nodal and a reference point.

- Signal elements: There are many natural and artificial elements marked as a landmark and attract attention in the deep-rooted history of Trabzon, which is a coastal and port city. The most prominent of these were Sumela Monastery, Ganita, Boztepe, Hagia Sophia, the statue of Atatürk in the Meydan Park and the TS emblem. In the field study, urban images, legibility, spatial information gained through past experiences and the importance of direction and information boards were noteworthy.

In addition, they stated that there were serious deficiencies in the number and quality of directional signs (Figure 5).

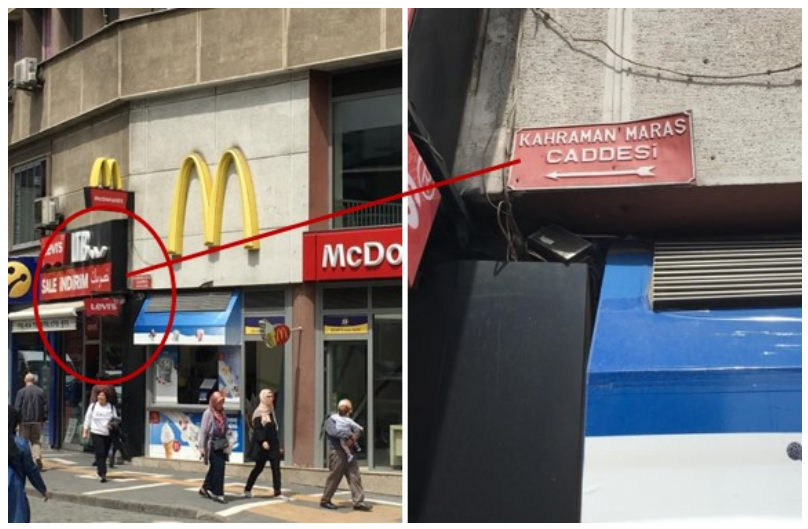

Figure 5. Directional signs of study field, Trabzon city (Ataoğlu, 2019). 
Direction/information designs that encode a city into our minds with "roads, monuments, regions, borders and signs" should be more carefully evaluated. Direction and information designs, which are multidisciplinary fields that direct and inform the user in the growing and complexifying urban space and interior space, serve as a subbranch of graphic design in expressing the character and identity of the space. City directors should be aware of this discipline and follow developments in order to adapt to the rhythm of the rapidly changing world.

\section{Acknowledgement}

This research did not receive any specific grant from funding agencies in the public, commercial, or not-for-profit sectors.

\section{Conflict of interests}

The authors declare no conflict of interest.

\section{References}

Ataoğlu, N. C. (2009). Çağdaş Mimaride Bir Antitez: Sirkülasyon [An Antihesis in Contemporary Architecture: Circulation Spaces] KTU]. Trabzon, Turkey.

Ataoğlu, N. C. (2019). Fotoğraf arşivi [Photo archive].

Bentley, I. (1985). Responsive Environments: A Manual for Designers. Architectural Press.

Carmona, M., Heath, T., Tiesdell, S., \& Oc, T. (2003). Public Places, Urban Spaces: The Dimensions of Urban Design. Architectural Press.

Demirbaş, Ç. Ö., Türkyılmaz, M., \& Armut, M. (2017). Üniversite Öğrencilerinin Kırşehir Şehir Algıları [KIRSEHIR CITY PERCEPTIONS OF

UNIVERSITY STUDENTS. Current Debates in Public Finance, Public Administration \& Environmental Studies, 13, 539-560. https://dergipark.org.tr/download/article-file/389869

Dur, B. İ. U. (2011). Çevresel Grafik Tasarım'ın Uygulama Alanlar1 [Application Areas of Environmental Graphic Design]. Sanat Ve Tasarım Dergisi, 1(7), 159-178. https://dergipark.org.tr/en/pub/sanatvetasarim/issue/2066 0/220408\#article_cite

Gibson, D. (2009). The Wayfinding Handbook: Information Design for Public Places. Princeton Architectural Press.

İlisulu, T. İ. (2017). BILLGILENDİRME TASARIMI VE EĞİTIMDEKİ YERİ [Information Design and Its Place in Education]. Journal of Research in Education and Teaching, 6, 195-213. http://www.jret.org/FileUpload/ks281142/File/18.tevfik inanc_ilisulu.pdf
Kaplan, S., \& Kaplan, R. (1989). Cognition and Environment: Functioning in an Uncertain World. Ulrich's.

Kayaoglu, I. G., Ciravoglu, O., \& Akalin, C. (Eds.). (1997). Bir Tutkudur Trabzon, Trabzon Simgeleri [Trabzon is A Passion, Trabzon Icons]. Yapı Kredi Yayınları

Kolody, A. D. (2002). Planning for Physical Activity: The Need to Comfortable and Convenient Pedestrian Movement in the Urban Form. University of Calgary, Faculty of Environmental Design.

Lynch, K. (1960). Kent Imgesi [The Image of City]. Turkey Isbank Cultural Publications.

Özbay, Ö. (2008). ÇAPRAZ TABLO ANALİİ NASIL YAPILIR?: PRATİK BİR

AÇIKLAMA [How to Make A Cross-Table Analysis ?: A Practical Description]. Journal of Turkish Studies in Hacettepe University(9), 459-470. http://www.turkiyat.hacettepe.edu.tr/dergi/9Sayi.pdf

Passini, R. (1984). WAYFINDING IN ARCHITETURER. Environmental Design Series, 4, 59-60. https:/ci.nii.ac.jp/naid/10012064885/

Passini, R. (1996). Wayfinding design: logic, application and some thoughts on universality. Design Studies, 17(3), 319-331. https://doi.org/10.1016/0142-694X(96)00001-4

Peponis, J., Zimring, C., \& Choi, Y. K. (1990). Finding the Building in Wayfinding. Environment and Behavior, 22(5), 555-590. https://doi.org/10.1177/0013916590225001

Sönmez, B. E., \& Önder, D. E. (2015). Bir tasarım ölçütü olarak yön bulma kavramı: tanımlar ve tartışmalar [Concept of Wayfinding a Design Criteria: Definitions and Discussions]. Megaron, 10(3), 355-364. https://doi.org/10.5505/MEGARON.2015.89421

Sternberg, E. (2000). An Integrative Theory of Urban Design. Journal of the American Planning Association, 66(3), 265-278. https://doi.org/10.1080/01944360008976106

TaŞÇIoĞLu, M., \& Aydin, D. E. (2015). Grafik Tasarımın Bilgilendirme ve Yönlendirme Tasarımındaki Rolü ve Londra-Eskișehir Örnekleri Üzerinden Bir İnceleme Dergisi [The Role of Graphic Design in Information and Direction Design and A Study on London-Eskişehir Samples]. Sanat Ve Tasarım Dergisi, 5(2), 227-245. https://doi.org/10.20488/austd.19088

$U R L-1$. (2017). https://sinalizar.files.wordpress.com/2011/06/epsilon_of fice_19.jpg

URL-2 (2019). www.googleearth.com 
Yavuz, A. (2009). Kentsel yaya allşveriş sokaklarinda geçirgenlik kavramının değerlendirilmesi: Doğu Karadeniz Kentleri Örneği [Studying The Concept of The Permeability in The Urban Pedestrian Shopping Streets; Sample of The Eastern Black Sea Cities] KTU]. Trabzon, Turkey.
Yavuz, A. (2019). Fotoğraf arşivi [Photo archive].

Check for

How to Cite this Article:

Yavuz, A., Ataoğlu, N.C. and Acar, H. (2020). The Identification of The City on The Legibility and Wayfinding Concepts: A Case of Trabzon. Journal of Contemporary Urban Affairs, 4(2), 1-12. https://doi.org/10.25034/ijcua.2020.v4n2-1 